\title{
Snapshots from the Borders - Participatory investigation: Tenerife
}

Authors:

Daniel Buraschi and Julio Ramallo Rodríguez Immigration Observatory of Tenerife (OBITen)

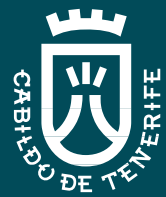


Edit: Immigration Observatory of Tenerife (OBITen)

Title: Snapshots from the Borders - Participatory investigation: Tenerife

Authors: Daniel Buraschi and Julio Ramallo Rodríguez - Immigration Observatory of Tenerife (OBITen)

Edition: May, 2019

Design and layout: Javier Cabrera S.L.

DOI: https://doi.org/10.25145/r.obitfact.2019.05 


\section{Table of contents}

The context of immigration in Tenerife

Immigration in civil society

Good practices at local level

Limits of action and challenges

Integration and citizenship

Conclusions

26

Bibliography

Annex. List of interviews 
"Snapshots From The Borders" is a 3-years project, co-funded by the European Union and run by 36 partners, border local authorities and civil society organisations, led by the Lampedusa and Linosa municipality. The main general objective of the project is the improvement of the critical understanding of European and local decision and law makers, civil servants, opinion leaders, public opinion and citizens about the topic of migration flows towards European borders. Our aim is strengthening a new horizontal, active network of cities and towns directly facing migration flows at EU borders, as a way to promote more and more effective policy coherence at all levels. The final perspective and framework is to achieve UN Sustainable Development Goals.

This report has been carried out through the analysis of secondary statistical data sources available at the national and local levels; the results of different empirical investigations undertaken by the Immigration Observatory of Tenerife in the last 15 years; and 23 semi-structured interviews with university experts, representatives from immigrant associations, professionals from NGOs, immigrants and their children, political representatives, technicians from the local governments, and participants in social movements linked to the defence of human rights. All the interviews have been recorded on video and a script with questions has been used, based on this report's structure, but with the questions adapted to the profiles of each person interviewed. 


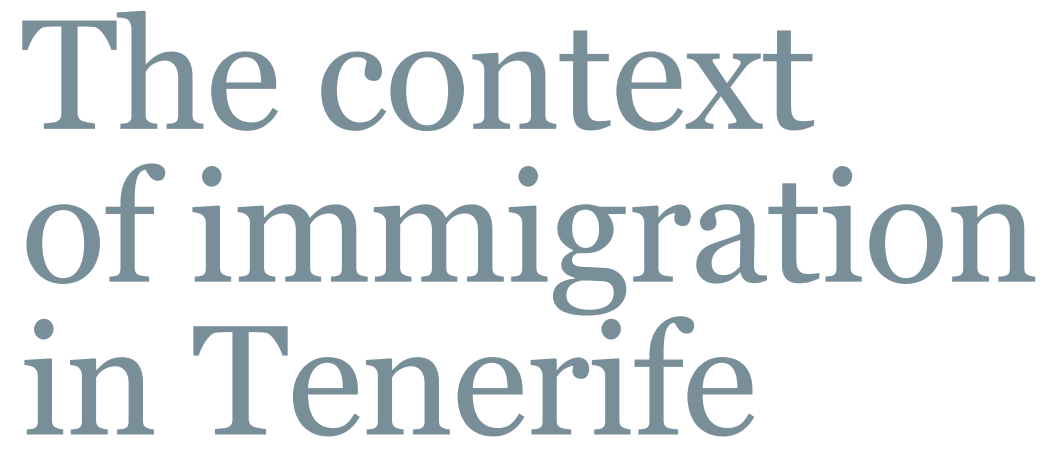

Historically, the Canary Islands have seen "major episodes of emigration" in economically difficult times" $\left(\mathrm{E} 1^{2}\right)$. Beginning in the seventeenth century, there was an intense migratory movement towards Latin America, especially to Cuba and Venezuela, which was to last until the 80s of this past century (Macías, 1992), when the migration flow changed directions and the Islands began to receive more immigrants (Godenau y Zapata, 2008). This migratory history has become an important part of the identity of the Canary Islands. Many of those interviewed remarked that one of the main keys to understanding the relationship that the Island of Tenerife has with migratory phenomena is that "the people of the Canary Islands have always been a people of emigration.” (E2, E6, E7, E14 y E17). This migratory past, especially in the case of Venezuela, is very present in Canarian society: the high number of people of Venezuelan origin, the high proportion of Canary Islanders who have family members who emigrated in past decades, the presence of numerous Venezuelan shops, businesses, and restaurants are all proof that the Canary Islands and Venezuela are like two peas in a pod when speaking of international immigration (Buraschi, 2014). Even so, emigration from the Canary Islands has not only flown towards Latin America; in addition, it has also involved European countries (E1) like Germany, the Netherlands, and Belgium (E17), as well as countries of East Africa. Beginning in the 90s, and more intensely between 2000 and 2007, the Canary Islands was transformed, like the rest of Spain, into an immigration destination - especially in terms of immigrants from Europe and Latin America (Asín-Cabrera y Godenau, 2014).

In 2017, the population living in Tenerife reached 895 thousand people (Table 1), of whom 177 thousand $-19.8 \%$ - had been born abroad, and 104 thousand $-11.6 \%$ - held a foreign nationality. The difference of almost 74 thousand individuals is mainly due to the naturalization of immigrants as they settled in Spain and the immigration of individuals with Spanish nationality born abroad - both phenomena that arise more frequently amongst those

\footnotetext{
1 In this report, we understand an immigrant to be any person who moves or has moved over an international border and outside of his/her usual place of residence. In this sense, emigration includes people who are residents of the Canary Islands and move to a foreign country, and immigration includes people of foreign origin who take up residence on the Canary Islands.

2 Throughout this report, due to reasons of space, the interviews will be referred to by their code and not by citing the name and position of the individual interviewed. See annex.
} 
of American origin. This can be seen in the fact that the population born in American countries represents $10 \%$ of Tenerife's population, but only $3 \%$ when taking into account the corresponding American nationalities (CHART 1).

CHART 1

Residents of Tenerife by place of birth, nationality and origin in 2017 and change with respect to 2000.

Source: ISTAC. Population Register on January 1 of the year.

\begin{tabular}{|c|c|c|c|c|c|c|c|}
\hline \multirow[b]{2}{*}{ Origin } & \multicolumn{3}{|c|}{ By place of birth } & \multicolumn{3}{|c|}{ By nationality } & \multirow{2}{*}{$\begin{array}{l}\text { Native/ } \\
\text { foreigner } \\
\text { ratio (\%) }\end{array}$} \\
\hline & Population & $\%$ & $\begin{array}{l}\text { Chg (\%) } \\
2000-17\end{array}$ & Population & $\%$ & $\begin{array}{l}\text { Chg (\%) } \\
2000-17\end{array}$ & \\
\hline Total & 894,636 & 100.0 & 26.1 & 894,636 & 100.0 & 26.1 & \\
\hline Foreigner & 177,456 & 19.8 & 233 & 103,703 & 11.6 & 231.7 & 171 \\
\hline Rest of EU-28 & 64,075 & 7.2 & 163.7 & 59,635 & 6.7 & 192.9 & 107 \\
\hline Rest of Europe & 6,173 & 0.7 & 450.7 & 5,243 & 0.6 & 602.8 & 118 \\
\hline Africa & 10,104 & 1.1 & 261.8 & 6,808 & 0.8 & 388.4 & 148 \\
\hline America & 87,999 & 9.8 & 294.7 & 25,681 & 2.9 & 280.3 & 343 \\
\hline Asia & 8,972 & 1.0 & 233.3 & 6,287 & 0.7 & 216.7 & 143 \\
\hline Oceania & 133 & 0.0 & 38.5 & 49 & 0.0 & 69.0 & 271 \\
\hline
\end{tabular}

At the beginning of 2017, Tenerife was home to $42 \%$ of the resident population of the Canary Islands. Its share of the regional foreign population was $45 \%$, and $47 \%$ of the foreign born population. If we look at the evolution of the immigrant population on the different islands (GRAPH 1), we can see that Tenerife shared, with all the other islands, strong growth in this population during the financial boom between the years 2000 and 2007, followed by stagnation during the subsequent financial crisis. The percentage reached by the population born abroad and residing in Tenerife was at a level that was clearly less than that on record in Fuerteventura and Lanzarote, but still it was substantially higher than that on record for Gran Canaria.

GRAPH 1

Trend in the percentage of the population born abroad by island betwen 1997 and 2017

Source: ISTAC Population Register on January 1 of the year.

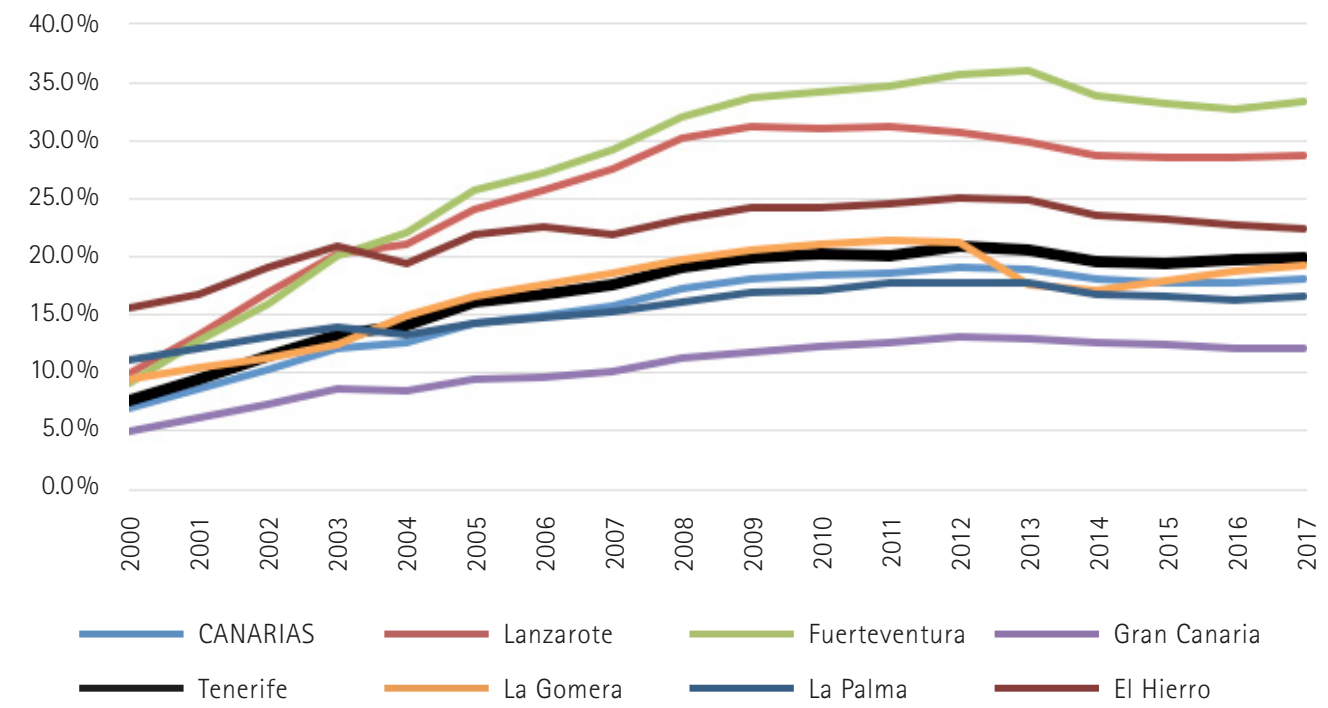


The territorial distribution of the immigrant population on Tenerife (MAP 1) (Adeje, Arona, Santiago del Teide, Granadilla de Abona, Guía de Isora, San Miguel de Abona, Puerto de la Cruz) reflects the importance of the specific economic and residential makeup of the region. It is in tourist towns where the percentage of population from other countries is greater. In contrast, in the municipalities that are less geared towards the service sector, these percentages are frequently below $10 \%$. Because of the different sizes and weights of the populations within Tenerife, the territorial distribution of the absolute number of people originating from another country follows a relatively concentrated pattern: $70 \%$ of this population resides in just 5 of Tenerife's 31 municipalities: Santa Cruz de Tenerife, San Cristóbal de La Laguna, Arona, Adeje and Granadilla de Abona.
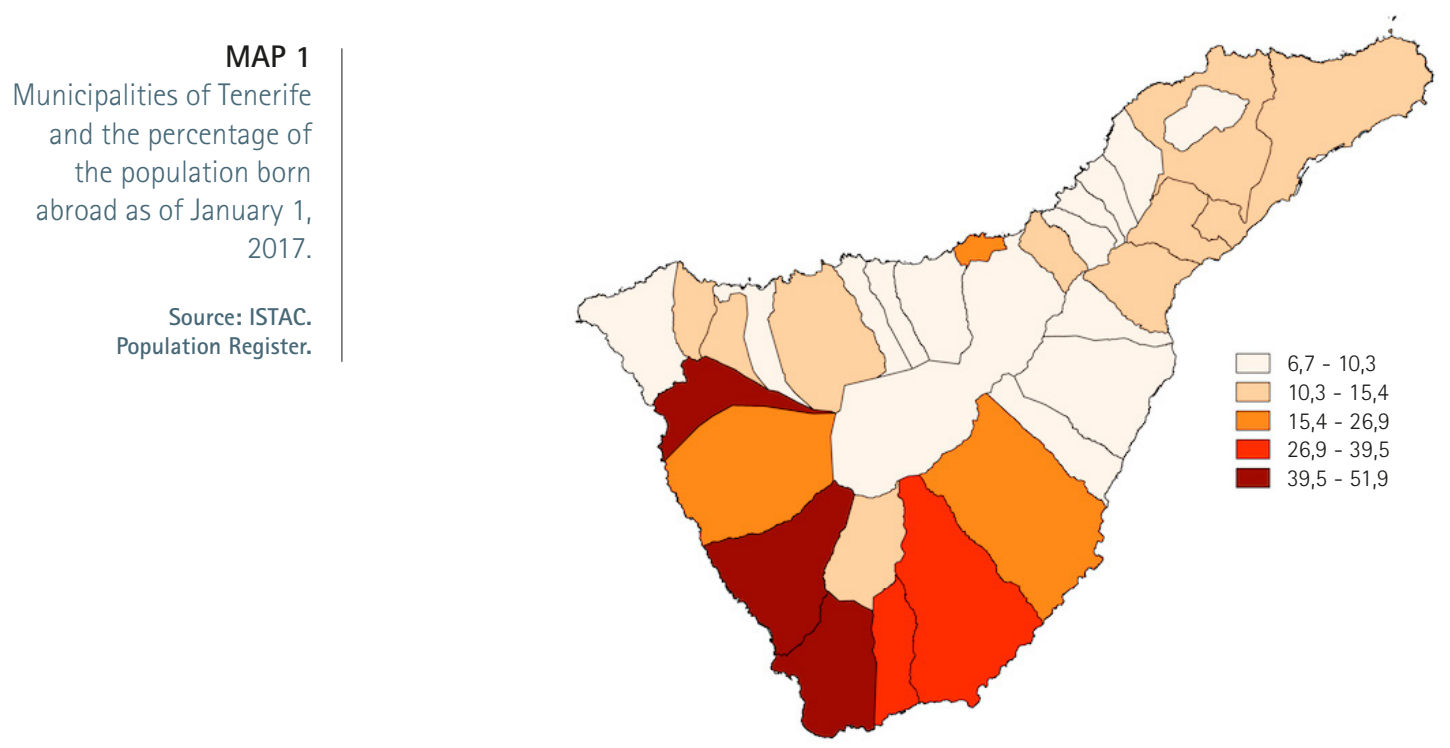

The Canary Islands have been, historically, a place of both emigration and immigration. The migration flows towards the Canary Islands have intensified over the last three decades. At the beginning of the 90s, this flow of immigrants was overwhelmingly from Europe and Latin America. In the year 2000, the number of foreigners reached $7 \%$, of which $45 \%$ were European, $11 \%$ of African origin, $37 \%$ of American origin, and $7 \%$ of Asian origin. In the year 2017, those proportions were almost identical. Having said that, the flows have intensified with regard to the year 2000 (currently, $18 \%$ of the Canary Island's population is of foreign origin) and the only significant change is that the most numerous collective is American, especially from Venezuela.

The population of Tenerife is made up of people from a wide range of backgrounds and nationalities: the population born abroad represents 170 different countries. The most common backgrounds (CHART 2) are American (Venezuela, Cuba, Argentina, Colombia) and European (Italy, UK, Germany). In the tenth place in the origin ranking is the first African country: Morocco. The historical migratory bonds between the Canary Islands and Cuba, and 
CHART 2

Top 10 countries and areas of origin or nationationality of the resident immigration population of Tenerife in

2017.

Source: ISTAC Population Register, on January 1.

\begin{tabular}{|c|l|r|r|l|r|r|}
\hline \multirow{2}{*}{ Range } & \multicolumn{3}{|c|}{ Population born abroad } & \multicolumn{2}{c|}{ Population of foreign nationality } \\
\cline { 2 - 7 } & Country & Population & $\begin{array}{r}\text { Chg (\%) } \\
2000-17\end{array}$ & Country & Population & $\begin{array}{c}\text { Chg (\%) } \\
2000-17\end{array}$ \\
\hline 1 & Venezuela & 38,223 & 163.2 & Italy & 17,331 & 814.0 \\
\hline 2 & Italy & 17,540 & 738.8 & United Kingdom & 11,793 & 74.7 \\
\hline 3 & Cuba & 16,637 & 490.6 & Germany & 8,639 & 30.8 \\
\hline 4 & United Kingdom & 12,826 & 66.0 & Venezuela & 7,676 & 166.0 \\
\hline 5 & Germany & 9,758 & 24.5 & 2004 EU expansion & 6,130 & $2,648.9$ \\
\hline 6 & Argentina & 8,001 & 392.1 & Cuba & 4,383 & 229.1 \\
\hline 7 & Other American & 7,796 & 425.0 & Other European countries & 4,380 & $1,215.3$ \\
\hline 8 & Countries & 7,775 & $1,406.8$ & Romania & 3,566 & $4,994.3$ \\
\hline 9 & 2004 EU expansion & 6,240 & $2,202.6$ & Argentina & 3,547 & 358.3 \\
\hline 10 & Morocco & 5,428 & 219.9 & Other American countries & 3,418 & 312.8 \\
\hline
\end{tabular}

later with Venezuela, can be seen in the great percentage of people born in those countries who have Spanish nationality. Likewise, populations from Venezuela and Italy have experienced strong growth recently.

The immigrant population's structure in terms of age and sex is not substantially different from the Spanish population pyramid in terms of the Island's residents (GRAPH 2); in both cases, the weight of the more middle ages is higher. Differences are limited to a degree of aging that is somewhat less in the foreign population and, likewise, a lower presence of minors.

GRAPH 2

Population of Tenerife by age and sex on January 1, 2017 (\%). Foreign population in left panel, Spanish population in right panel.

Source: ISTAC Population Register.
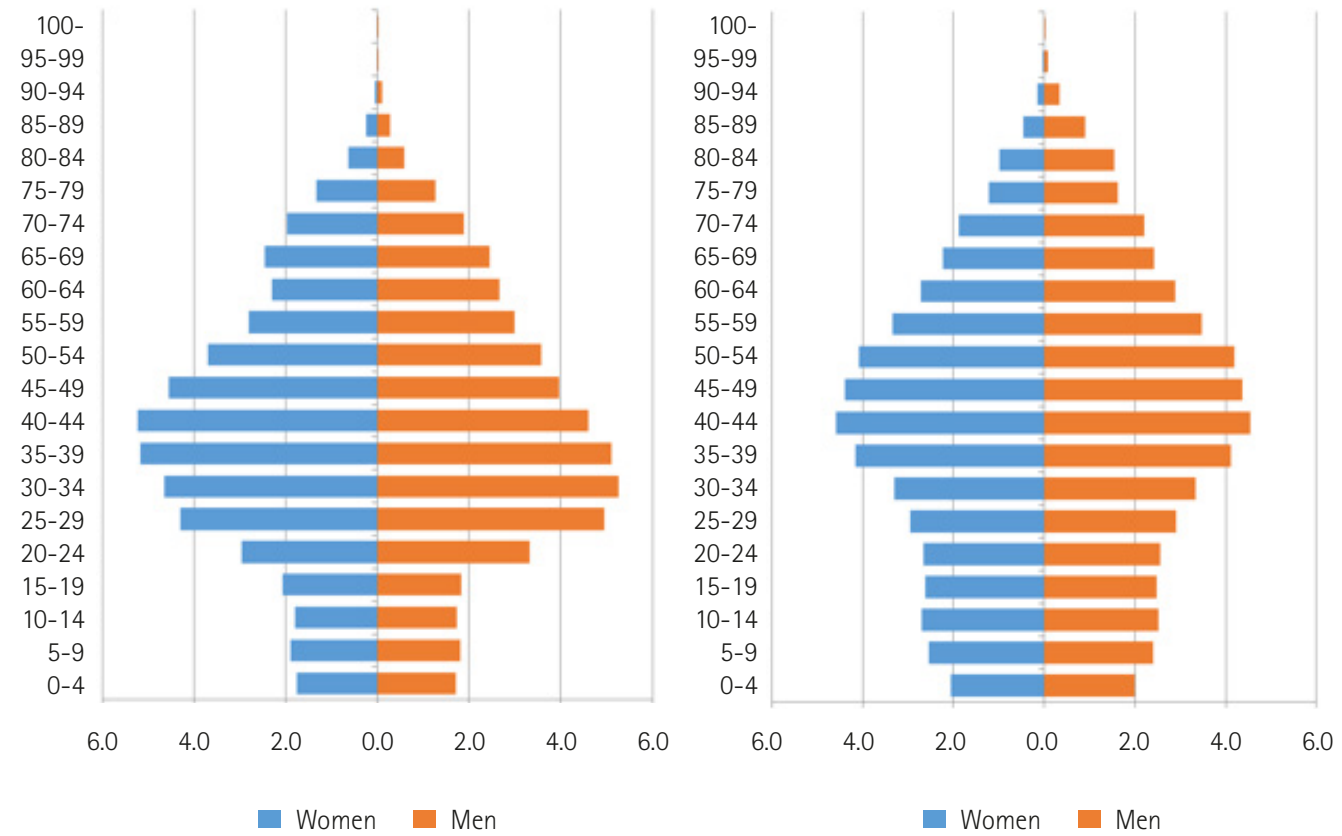
Nevertheless, this general situation is the result of an overlapping of age and sex figures that are clearly different amongst the different origins of the immigrant population. Due to the work-related motives of many of those who migrated from non-European countries during the economic boom, said population arrived to the Canary Islands with relatively young ages. In contrast, in terms of European immigration, there is a large portion of elderly people who come to Tenerife for residential reasons and who do not participate on the job market.

Turning now from the characteristics of the immigrant population to migrant flows; that is to say, the number of people who enter and leave the Island of Tenerife, new records in the municipal register (immigration) and record cancellation in the municipal register (emigration) allow us to approximate foreign migration figures (GRAPH 3).

During the 2002-2016 period, there were three different stages or phases. The first, which lasted until 2007 and occurred in a context of economic growth, had a high migratory balance (net immigration); the second, from 2008 to 2015, showed the signs of the financial crisis with a sharp reduction in the migratory balance, even reaching moderately negative figures in 2015, and the third, which started in 2016, showed the consequences of economic recovery, with greater levels of immigration and a reduction in emigration. (Domínguez y Díaz; included in Godenau y Buraschi, 2017b).
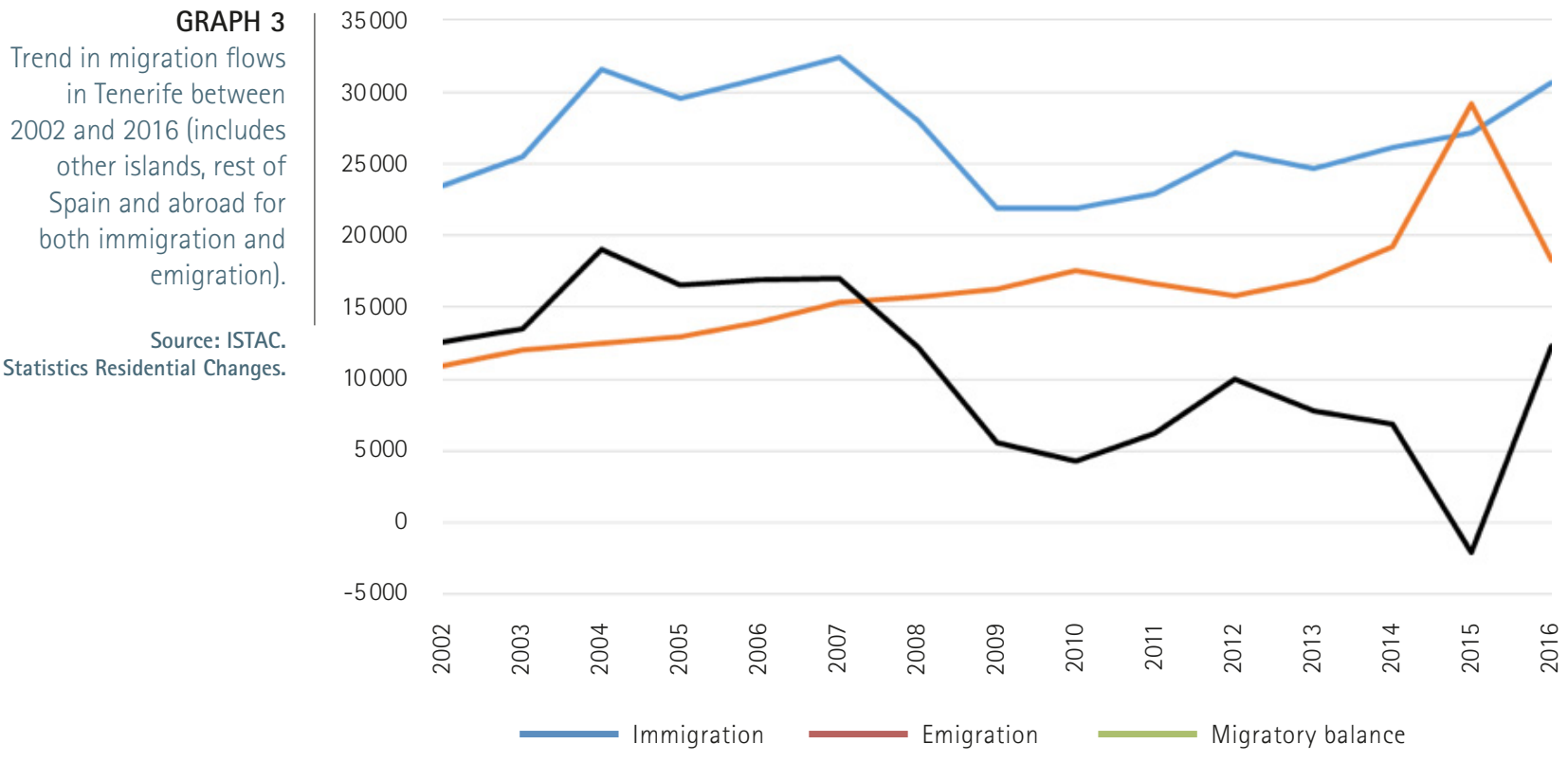
Migration flows can be classified by the government as regular or irregular ${ }^{3}$. For the case of irregular migration, it is important to differentiate between illegally crossing the border (for example, arrival via the sea in rafts and rudimentary "cayuco" boats) and simply staying in the country without the corresponding residence permits. Those who cross the border illegally do not necessarily stay in the place where they arrived, as they may move on to other territories or, if they are intercepted, they may be sent to other places by the authorities. Likewise, entrance into the country may be legal (for example, as a tourist arriving through an airport); however, a subsequent irregular situation may arise if the individual stays without the necessary residence permits.

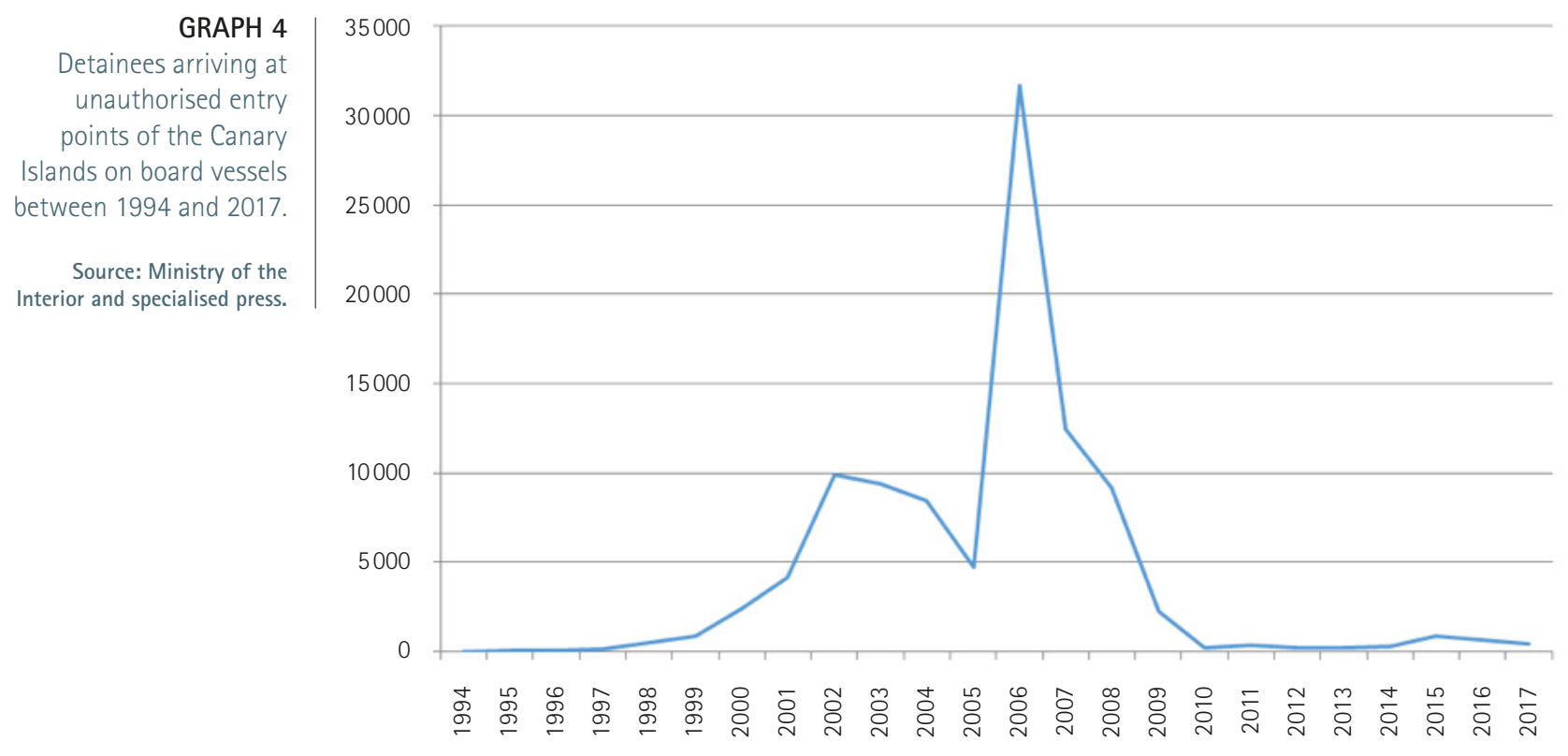

As part of the Atlantic route of African emigration towards Europe, the Canary Islands is the place of arrival for those who embark from the western coast of our neighbouring continent so as to gain access to the European Union. From the years 2002 to 2008, these arrivals were much more numerous than in prior and later years (GRAPH 4), reaching a notable peak in 2006 during the so-called "cayuco boat crisis." Currently, said flow is at a lower level and reactivation of the Atlantic route will depend on events in the Eastern and Western Mediterranean routes, which are now relatively more permeable. In 2017, 418 people arrived from the coasts of Africa in 16 watercrafts. This is a very low number if compared with the year 2006, when there were 31,678 people recorded. The profile of those who arrived in this way in 2017 was made up of adult males (87.7\%), minors (8.7\%), and women (3.5\%). The majority

3 "Immigrants in irregular administrative situations," also called "irregular immigrants" or (incorrectly) "illegal immigrants" are those that do not have the necessary documentation to enter and reside in Spain legally. There are generally three types of irregular immigration status: 1. Immigrants who arrive to the Islands by sea without following the legal requirements for Spain; for example, some immigrants of African origin. 2. Those who enter with a visa or tourist authorization and who stay to live on the Islands without a residence permit once their initial visa or tourist authorization has expired (currently, this is the main irregular way of entering Spain). 3. Those of foreign origin who had a work permit and lost it due to the fact that they lost their job. 
of the watercrafts depart Morocco or the Western Sahara, but there are also some that embark on their journey from Senegal and The Gambia (CEAR, 2017). Preliminary data for 2018 shows incipient intensification of said inflow, surpassing one thousand arrivals for the first time in nine years.

The Canary Islands represents for these migrants a land of passage - a first stage on their trip towards Europe, more specifically, towards France and Germany. Nevertheless, irregular immigration by sea represents a very small portion of the whole of the immigrants who arrive to the Islands; the vast majority of them choose the islands as their place of residence - that is to say, as the final destination of their migratory process.

Migration policy. Spanish migration policy in relationship with the management of migration flows is handled by the State, while policies for integration have been developed mainly on a local level, where the Autonomous Communities and municipal bodies take centre stage (Alonso, 2011). Policy in the period stretching from 2000 to 2008 was characterized by "opening the door to illegal entries in a context in which there is a demand for unskilled labour that cannot be filled." (E1) It was a policy focused on fighting (partly) against illegal immigration and regulating the job market. It turned, on different occasions, to processes for the extraordinary regularization and normalization of foreigner's situations (years 2000, 2001 and 2005), reflecting the paradox of a policy that was formally restrictive but, in practice, permissive (Godenau, 2010). This contributed, along with the expansion of the underground economy, to an increase in illegal immigration (López-Sala, 2013). During this period, a national policy for integration began to take shape with the passing of the Strategic Plan on Citizenship and Integration (20072010) and of many Autonomous Region plans; for example, the Canary Island Plan on Immigration (2002-2004 and 2006-2008). Beginning in 2008, a "on the defensive" policy began to prevail (Izquierdo, 2008), characterized by reinforced border controls, outsourcing of border control, measures to promote the return of immigrants, and the almost entire disappearance of funds for social integration - bringing about great setbacks for social intervention on a local scale. (E7, E8 y E19).

Beginning in 2008 in Tenerife, the vast majority of social intervention projects involving immigrants started to disappear due to a lack of funding (E22). Spanish immigration policy has continued to not "set requirements in terms of the qualifications and origin of immigrants, leaving this selection in the hands of the labour market (occupations that are hard to find workers for, hiring in the country of origin). (Godenau, 2010: 19)" 


\section{Immigration in civil society}

Public opinion on immigration. In the last few years, support in favour of more restrictive immigration policies is gaining strength in the European countries Anaya, Aguilar y Bautista, 2018).. The periodic Eurobarometer surveys show, above all beginning with the so-called "refugee crisis" in 2015, an increased feeling of rejection towards migrants and a more negative perception of immigration in general. This tendency is not evident in Spain where, as Rinken (2015) points out, a "calmer" discourse on immigration tends to be more dominant. By comparing the data from the Eurobarometer, we can see that, in terms of the question about the perception of immigration in one's own country, $63.0 \%$ of those surveyed in Spain had a positive or very positive perception, while the European average for the same question was only 40.0\%. In line with the proposal made by Rinken (2015), we can identify at least three factors that must be taken into account to interpret these results: the first important factor is that, in Spain, there is a post-Franco culture that limits the expansion of extreme-right political parties, promoting, additionally, a more universal view in terms of civil and social rights. A second element to take into account is that attitudes are not always reflected through direct expression; that is to say, social desirability bias could play an important role in the under-representation of xenophobic attitudes. A third element is that criticism toward the elite, which has been intense, especially through the social anti-austerity movements of May 15, 2011, is keeping the discontent from focusing on immigrants. In other words, the "vertical struggle" has inhibited the "horizontal struggle" between those in a situation of social exclusion. The latest report by the Observatory on Racism and Xenophobia, which analysed the data of the CIS barometer until 2015, is in line with this reasoning and it notes the uniqueness of the case of Spain in a European context (Fernández, Valbuena y Caro, 2017). According to the data of this report, $54 \%$ of Spaniards see immigration as something positive, compared with $31 \%$ who see it as something negative. The most important factors that stand out in favour of foreigners living in Spain are "for them to be willing to adopt the country's lifestyle" and "for them to be qualified to work in professions that Spain needs." The more negative aspects are that immigrants "take away jobs" (58\%) and make salaries go down (76\%). Nevertheless, around $80 \%$ believe that the immigrants who reside in a stable way in Spain should be granted nationality over time; more than $85 \%$ of those surveyed feel that said immigrants should be able to bring their families, and more than $90 \%$ agrees with them collecting unemployment. 
In terms of attitudes towards the immigration of those who reside on the Island of Tenerife, is it necessary to add other factors to the three factors already mentioned. These factors are inherent to the context of the Canary Islands and have been noted frequently by those interviewed: the migratory past of the Canary Islands, with strong, intense bonds with Latin America (E1, E2, E3, E6, E7, E12, E17); the history of the Canary Islands as a welcoming place (E1, E3, E17, E19); the low level of xenophobic discourse in politics, the media, and society (E3); the low level of spatial segregation (E1) and preventative programs that have a community, participatory nature and which, like a "light rain", (E2) have positively influenced both the civil society and the institutions. (E3 y E6).

The perception of the migrants interviewed is that, on the Island of Tenerife, attitudes are generally positive and the Canarian society is open to individuals (E17) who come from abroad (E1, E2, E14 y E20). Having said that, at times it is noted that there are cases of discrimination, especially in terms of access to work (E4), access to housing and in selective police checkpoints (racial profiling 4 ) (E19 y E20). The perception of discrimination is quite linked to phenotypic traits (E10 y E2O) and the use of religious symbols like the hijab (E4).

In terms of data on the attitudes of the Canary Islanders towards immigration, there are currently three sources of information: the results yielded by the Canary Island Social Barometer, undertaken on the Island of Tenerife within the context of the "Anti-Rumour Strategy to Combat Racism and Xenophobia" and by the previous survey to evaluate intercultural coexistence, part of the 2015-2017 Strategic Plan by "Juntos en la misma dirección" ("Together in the Same Direction"). The scarce number of studies on this topic caused the Immigration Observatory of Tenerife (OBITen) to begin, in 2017, with a comprehensive study on the perception of immigration on the Island of Tenerife, including a survey of a representative sample of the population residing on the Island (both of Spanish and foreign origin), discussion groups, and interviews whose results will be published in 2019.

The Canary Islands Social Barometer (2007 and 2010), provides information on matters related with immigration: the perception of the positive or negative impact of immigration, the need of immigrant workers, and a view of immigration as a problem. In response to the question asking respondents to rate immigration from other countries towards the Canary Islands on a scale from "very negative" (o) to "very positive" (10), the average from the second wave in 2010 was $M=3.82$. This indicates an assessment that was less positive than that yielded in 2007 , when the average was $M=4.48$. In terms of the question about a need for immigrant workers on the Canary Islands, responses show a clear decrease in affirmative answers from $46.2 \%$ in 2007 to $24.4 \%$ in 2010. Lastly, regarding the question about what the main problems

4 "Racial profiling;" that is to say, the practice of using ethnic or racial stereotypes instead of individual behavior, suspect descriptions, and accumulated knowledge to undertake police checks. 
for Canarian society are, immigration went from $23.5 \%$ to $6.1 \%$ (Government of the Canary Islands, 2010). The first two results may reflect the impact of the financial crisis on the perception of immigration on the Canary Islands, while the third result shows the importance of the media's impact during the "cayuco boat crisis" in terms of public opinion.

The diagnosis carried out in the context of the "Anti-Rumour Strategy to Combat Racism and Xenophobia," promoted by the Tenerife Island Council, identified the main stereotypes and prejudices towards immigrants who reside on the Island. Said diagnosis was carried out through semi-structured interviews and questionnaires which have shown that the main stereotypes about immigrants are as follows: they take unfair advantage of social assistance and aid, they have a negative impact on the job market, and they overuse the health system.

Lastly, in terms of the 2015-2017 Strategic Plan by "Juntos en la misma dirección" ("Together in the Same Direction"), a survey was undertaken on a representative sample of the Island's population to study different aspects related with intercultural coexistence. Said survey found that Tenerife was characterized by a scarcity of significant conflicts that continue over time and are caused by cultural diversity and/or the origin of its residence and by the abundance of citizens' initiatives seeking understanding and coexistence within the context of the melting pot that is our region. The results of said survey showed that $62.9 \%$ of the population surveyed said they were aware of the benefits of cultural diversity. $61.9 \%$ of those surveyed frequently relate with people from cultures other than their own.

The media and immigration in Tenerife. Regarding the image of immigrants in the local media, it must be noted that during the so-called "cayuco boat crisis" (2006-2007), illegal immigration was at the forefront of media attention (E2) with a variety of approaches to the news ranging from "humanitarianism" to "security concerns," (Rodríguez-Borges, 2010) and the image of immigration transmitted by the media was linked to the African immigrant prototype (Ardevol, 2008). Nevertheless, currently, although the media continues to focus a lot of its attention on illegal arrivals from Africa, thanks to the close cooperation between some intercultural projects and the media, the positive aspects of coexistence and intercultural initiatives are seen more and more. This greater degree of visibility is due, likewise, to the fact that the government has made some of the elements of intercultural discourse its own. Despite this greater presence, the voice of immigrants in the media continues taking less prominence than desired (E18).

The social impact of the refugee crisis and actions of civil society. The so-called "refugee crisis" has had -as in the rest of Spain- a limited political and social impact compared with other European territories. This is a crisis that Canarian society has experienced indirectly, not being in the spotlight 
of the political, social, and media agendas. Nevertheless, the publication of Aylan Kurdi's photograph (El-Enany, 2016; E18) was an important turning point and, beginning in the first week of September of 2015, several citizens' initiatives were undertaken, being linked with welcoming refugees and characterized by two elements: firstly, these are initiatives that have realized the value of, and capitalized on, the participatory work of community projects and social movements that had been functioning for many years in the region (E18),and, secondly, new initiatives have been generated, characterized by a participatory, local approach with close cooperation between citizens, institutions, and professionals who work with immigrants.

In September of 2015, for example, the "Candelaria por la paz y el derecho al refugio" ("Candelaria for Peace and the Right to Refuge") Collective came to be - a collective that links itself to the "Barcelona Refuge City" citizens' initiative and promotes cooperation with local authorities for them to accept the challenges and opportunities to take in refugees (E18). That same month, the "Bienvenidos Refugiados" ("Welcome Refugees") Platform came to be, in the bosom of similar initiatives on a national and European level, carrying out -especially in 2016- intense work to raise awareness, support, and defend the rights of refugees.

Actions of civil society. The Island of Tenerife is characterized by the existence of numerous participatory experiences tied to intercultural coexistence and social inclusion. The main player of these initiatives is the civil society (E2, E5, E6 y E18), and said initiatives are based on the principle of community empowerment, which defends the idea that communities have the resources to be able to manage the challenges of coexistence and social cohesion (E2) in a creative and effective way. In many cases, these initiatives stem from community projects that began to get started a decade ago with immigrant associations and which have evolved to become cross-disciplinary community projects based on an intercultural approach. These are projects that are closely linked to the region, participatory, and which usually work in close collaboration with local institutions. In some cases, like the "Juntos en la misma dirección" ("Together in the Same Direction") Strategy, these are projects undertaken at the Canary Island level; in other cases, like the "Intercultural Community Intervention" Project (ICI Taco), these are projects on a local level.

There are different lines of social intervention with immigrants that involve members of civil society, both as volunteers in the projects and as participants in the undertaking of the activities: accompaniment in first contact services (especially volunteers from NGOs); advising and accompaniment services (like projects undertaken by the charities Cáritas and the Red Cross); activities designed to raise awareness and promote social advocacy (NGOs and different social platforms); activities to promote intercultural coexistence (this case does not use volunteers but instead participants). 
One example of a participatory project related with the citizens' response to the refugee crisis is the "Tenerife Antirrumores" ("Tenerife Anti-Rumor") Group. This is a participatory workgroup that is part of the strategy that has gradually taken shape around "Juntos en la misma dirección" ("Together in the Same Direction") since 2013, made up of people and entities that share the aim of improving coexistence on Tenerife by preventing racism and fighting against stereotypes and false rumours about the foreign population and the Island's cultural diversity. The "Anti-rumour Strategy to Combat Racism and Xenophobia" is an initiative backed by the Network of Intercultural Cities (RECI) and linked to the Council of Europe which has also been started in cities like Sabadell, Fuenlabrada, and Getxo by following the initial model of Barcelona. It is currently in expansion through different European territories (Buraschi, Aguilar y Zapata, 2016).

The novel idea around which the Barcelona Anti-Rumour Strategy is based, and what has acted as inspiration for Tenerife, is that any individual, in any context, can be a communicative agent for change. Having said that, the unique thing about Tenerife's strategy is that there has been special emphasis placed on the participatory dimension and on dialog, with Tenerife likewise taking into account alternative methodologies other than the "counterexample logic" methodology that was characteristic of the initial model - the result of a fruitful encounter between activism, local institutions, and scientific investigation (Zapata y Ramallo, 2015).

The backbone of the Anti-Rumours Strategy is intense participatory and group work which acts as a basis for the development of the rest of the dissemination actions directed towards the whole of civil society, amongst which dialog laboratories can be found.

As a result of the Tenerife Anti-Rumour experience in September of 2015, the "Comunicación Participativa Antirracista: claves para la acogida comunitaria" ("Anti-Racist Participatory Communication: Keys for Community Reception") Program was born, an initiative by the General Directorate of Social Policies and Immigration of the Government of the Canary Islands in cooperation with the General Foundation of the University of La Laguna. Its aim is to create a community reception network to value the skills, knowledge, and enthusiasm of the many people in our society who hold values of solidarity through the establishment of an extensive network of entities, groups, and people who coordinate their efforts and work to improve reception and defend human rights (Buraschi, Aguilar, Oldano, Fonte y Zapata, 2017).

Coordination of services. Coordination between the government at different levels (national, regional, and local), the civil society, and NGOs is quite heterogeneous and varies a lot depending on the project and the scope of action. Coordination between the civil society, technicians, and the government represents, for example, one of the main strengths of the main community 
intervention projects undertaken on the Island (E2, E3, E5, E6, E7, E12 y E19). There exist numerous channels and spaces through which the technical staff members of the NGOs and local government can interact: the "Mesa Técnica de Inmigración y convivencia Intercultural" ("Technical Roundtable on Immigration and Intercultural Coexistence" - City Hall of Santa Cruz de Tenerife), in which the main NGOs that work with immigrants participate; the Coalition for the Right to Healthcare, which brings together the entities that take care of access to healthcare for immigrants; and the "Mesa de Entidades Vinculadas al CIE de Hoya Fría" ("Roundtable for Entities Tied to the Hoya Fria Alien Internment Centre), which coordinates the activities undertaken in Alien Internment Centres. Additionally, different coordination initiatives (E2 y E6) are being organized and are gaining strength, such as coordination channels, cooperation between entities, associations, and local governments (Island Council Roundtables, Intercultural Open Space, etc.).

Although horizontal coordination between the local government and nonprofit entities does represent one of the main strengths, on Tenerife and in the rest of the Canary Island Chain (according to the technical personnel interviewed), a common, coordinated policy is lacking on the inclusion of immigrants so as to coordinate the different services on a regional level and, thus, ensure the project's sustainability (E6, E7, E12 y E19). 


\section{Good practices at local level}

On the Island of Tenerife, numerous local intervention experiences have been undertaken with immigrants, as well as experiences to promote intercultural coexistence, all of which have been recognized on the national and international levels (E2). Due to space limitations, we will only cite four of the aforementioned experiences: two focusing on promoting intercultural coexistence through a participatory approach and two geared towards advising and accompanying immigrants.

"Juntos en la misma dirección" ("Together in the Same Direction") is a network work strategy that has been promoted since 2009 by the Tenerife Island Council and the University of La Laguna (E2 y E3). This is a cooperative network made up of private individuals, immigrant associations and other types of associations, local governments, and NGOs whose aim is to promote dialog and intercultural coexistence through the undertaking of different participatory processes. More than 100 entities and associations and more than 2,000 people (E6) participate each year in the project's activities. These activities are designed in a participatory way through a unified intervention strategy based on the creation of different workgroups organized by theme: gender-based violence, childhood (E16), religious dialog, co-youth development, anti-racism, participation, etc. (E6). Each workgroup is organized autonomously, defending its agenda, its goals, its intervention strategies, and coordinating and cooperating with the other groups through numerous participatory spaces and channels (Mesa, Ramallo y Zapata, 2012). The effectiveness, sustainability, and impact of the "Juntos en la misma dirección" ("Together in the Same Direction") strategy depend on its ability to find its niche and become integrated into already-existing networks that play a central role in the dynamics of coexistence (Zapata, 2013). The strategy's backbone is a team of facilitators who are in charge of accompanying the workgroups and promoting and improving the creation of participatory networks and initiatives. The "Juntos en la misma dirección" "Together in the Same Direction") workgroup places great emphasis on maintaining relations (E6), coordination and cooperation between technical personnel, local governments, and citizens, and on the development of spaces for dialog and meeting between individuals of different origins without only focusing on immigrants but also on a process of community empowerment that involves the whole of society. 
The Proyecto de Intervención Comunitaria Intercultural ("Intercultural Community Intervention Project"- ICI Taco) (E5) is an initiative undertaken in the Metropolitan Area of the place known as Taco, striving for coexistence and social cohesion based on the strengthening of a community process in which the government, the technical/professional resources, and general citizens all play a joint role (Zapata, 2016). This is a project that has been undertaken successfully and effectively in forty territories throughout Spain since 2010, with Taco being added in 2014. The ICI projects, driven by "la Caixa Social Work" are an innovative initiative for community intervention and for the management of social and cultural diversity, as validated by their results and their impact on improving coexistence. In terms of the Taco area, ICI is managed by the General Foundation of the University of La Laguna and undertaken based on a cooperative agreement with the City Hall of Santa Cruz de Tenerife and the City Hall of San Cristóbal de La Laguna (Mba, Mesa y Zapata, 2017: 224, included in Godenau y Buraschi, 2017b). One of the elements that sets this project apart is that is promotes intercultural coexistence through a community empowerment process that includes neighbours' reassessment and re-identification of their area/neighbourhood (E5 y E14), including comprehensive citizen actions like CONviveTACO, community meetings, and open summer school; all of these actions have been designed and developed in a cooperative way based on community diagnosis and programming (González, Mesa y Zapata, 2016).

The Spanish Red Cross is, like in the rest of Spain, one of the main entities responsible for taking in immigrants and supporting them through their social inclusion process. The key to the Red Cross's good work in Tenerife is that it offers comprehensive services to immigrants (E19): from transfer and initial reception of those who have arrived irregularly to the island to comprehensive advising services (social, legal, psychological, and educational) that include: information, social advising, and remittance to internal and external resources; coverage by social emergency subsidies; accompaniment and support in relationship with administrative paperwork and financial paperwork; legal advising on immigration law; processing of documentation, accompaniment to the foreigner's office; personal, couple, and family care services and intervention services; training, Spanish classes, occupational guidance; management of self-help groups. Additionally, it has an innovative "family search, messaging, and contact reestablishment" service whose aim is to re-establish contact with families and/or acquaintances which, due to political causes, natural disasters, immigration, and/or humanitarian crises, have broken their relationship bonds.

Cáritas Diocese of Tenerife is carrying out a "migration program" and undertaking two lines of action: firstly, accompaniment for immigrants in situations of social vulnerability through the work of volunteers and the entity's technical staff; and, secondly, awareness raising and advocacy aiming to make the reality of migration more visible, promoting the creation of more inclusive 
and diverse societies that understand interculturality as an opportunity to grow. The Cáritas migration program has two facets that can be considered as good practices. Firstly, it has chapels throughout the territory (E7 y E8). The groups of volunteers and professionals who accompany immigrants are present in all the Archpriesthoods. Additionally, it mobilizes 900 volunteers to create a vast accompaniment network that is extremely heterogeneous and can be adapted to the needs of different immigrant profiles. 


\section{Limits of action and Challenges}

One of the main topics covered in the interviews was that of the limits and challenges of integration and intercultural coexistence on a local level. We must point out that, despite the fact that the profiles of those interviewed were quite heterogeneous (from younger boys and girls to immigrants, professionals, and researchers), there is a clear consensus in terms of the limits and challenges, which can be summed up in five large areas.

1. Rethinking the management policy for the migration flows is a key to human rights (E10), as well as activating different routes to regularization of migratory status and, above all, reformulating the refugee policy to make it easier to manage applications and ensure that there are reception resources while respecting international agreements (E18 y E19).

2. Ensuring resources so as to continue existing processes (E6, E7, E8, E12 y E19) and recovering the resources, means, and participatory and advisory (E22) channels that existed before the cutbacks of recent years (E23).

3. Defining a public policy for promoting coexistence (E6), that is comprehensive and inclusive and is based on co-responsibility; that is to say, it should take into account the whole of society (E2 y E3), because the processes for integration and coexistence are bi-directional and depend on society as a whole (E1, E2 y E8): "this is not a task for a few; instead, it is something for the whole of society, with each of its players (E2)." A policy that promotes equal opportunities through specific plans (E1 y E8).

4. Building a common, inclusive, plural, non-essentialist Canarian identity with which all people can identify (E13, E15). This implies raising awareness of plurality and diversity as endogenous parts of Canarian culture - not exogenous (E9, E15 y E17).

5. Continuing with the work to prevent racist and xenophobic attitudes (E9, E10, E11, E16), by countering populist booms through an appreciation of the host culture (E1); in other words, the challenge is "to respond to the global rise of populism in terms of actions that can be done locally (E5)." 


\section{Integration and citizenship}

In Spain, the law that regulates the entry and stay of non-EU immigrants, their rights, freedoms, and social integration is known as the "Immigration Law" (Organic Law 4/2000, and successive modifications, Organic Laws 8/2000, 14/2003, and 2/2009), whose regulations for implementation are included in Royal Decree 557/2011. As in the rest of Europe, in Spain there is a significant difference between the rights and freedoms of foreigners from an EU country, those of foreigners from outside the EU who are in Spain legally, and those who are in Spain illegally. While the first two profiles have social and political rights that are almost the same as those of Spanish nationality, those who are in the third group have very limited recognized rights - not only because of national regulations but also because of administrative practices at a national and local level that, sometimes, makes it impossible for them to access basic services and for the recognition of their basic rights (E8).

Access to the municipal register (municipal census registration). The Municipal register of inhabitants is used to prove one's residence and address in the municipality for administrative purposes. Registration with the municipal register is a compulsory formality which allows access to certain public services like healthcare, school, and social aid. Not only is it useful in order to have access to the services listed, but it is also one of the main documents used to prove the amount of time one has resided within Spain. It is, therefore, an essential record to be eligible for different ways of regularizing one's legal situation in Spain through the existence of social ties with the country (E20).

All persons, regardless of their nationality, can register with the municipal register; however, social workers, the NGO staff members, and the immigrants interviewed note that in some municipalities on the Island, registration is not allowed by those with an irregular immigration status, thus denying these people access to many basic municipal services and compromising access to the regularization of their situation (E8 y E20).

Access to healthcare. In Spain there is universal healthcare; however, in April of 2012, a decree-law (Royal Decree 6/2012) excluded irregular immigrants from said health coverage. This measure has caused a great impact 
Castelló (2018), exclusion of illegal immigrants has brought about an increase in said group's mortality of $15 \%$, which is equivalent to 70 deaths per year (E7). Those who are in Spain illegally only have the right to emergency care (due to severe illnesses or accidents - until the time of medical discharge) except for minors and pregnant women (pregnancy, birth, and postpartum care). Currently, the Government of Spain is once again starting to recognize access to healthcare for this group.

Access to the educational system and to other forms of training. Schooling on the Canary Islands, as in the rest of Spain, is obligatory and free for boys and girls from 6 years of age to 16 years of age. Legal foreign residents can access non-obligatory education, obtain the corresponding degrees, and access the public system of scholarships and grants. Additionally, they can choose from the different courses offered through the Spanish Public Employment Service. On the other hand, those who are in Spain illegally do not have access to said official courses and they often go to language courses or employment-related courses that are offered by NGOs. Regarding language courses, there are parallel contexts in which they are given: there are official courses like those offered by the Official School of Languages for those who have a legal immigration status, and language courses organized by NGOs like the Red Cross and Cáritas (E20).

One of the main problems noted by immigrants, especially those of Latin American origin, is recognition of university studies completed in their country of origin. The process for having a foreign university degree recognized is expensive, long, and -in many cases-complicated, as it involves the translation and legalization of all documents (diplomas, syllabi, grade transcripts, etc.). Delays in degree recognition, which in many cases exceed four years according to those interviewed, represent an important obstacle in immigrants' search for employment. Nevertheless, one of the main strengths in this area is that many educational centres have intercultural programs with vast experience in managing diversity (E13 y E16).

Regularization. Immigrants who are in Spain irregularly (either because they entered the country irregularly or as a result of entering and overstaying their visa) can regularize their immigration status in Spain through a temporary residency permit granted for exceptional circumstances, such as the existence of social or family ties in the country ("arraigo"). Normally, the "social ties" type of permit is the type that is most common, which allows a person to regularize their immigration status if they can prove "a path of social integration" (E8) that has lasted at least three years in Spain and that they have a work contract. Despite the fact that this is the most applied for type of exceptional residence permit, it is a complex process as the person must stay in Spain illegally for three years and needs a full-time employment contract to file the application. Those interviewed who have gone through this process share an experience of uncertainty, fear of police checks, loneliness, 
frustration, and difficulties supporting themselves. Additionally, they note the vulnerabilities that not "having papers" (E10) brings about: occupational exploitation in the underground economy, overcrowding in houses that are often unfit and -in some cases- do not have electricity and water (E20). To all of this, we must add the stress of searching for a full-time employment contract of at least a year in length in a context that is characterized by high levels of unemployment and precariousness (E14).

Nationality. In Spain, there are different ways to obtain Spanish nationality. Amongst them, the one that affects most foreign residents is "nationality by residence." This way of acquiring nationality requires that the person legally reside in Spain for 10 years. Said residence must be continuous and immediately prior to the application for nationality. However, there are cases when the period of residence is reduced, and these cases are: 5 years to grant Spanish nationality to those who have obtained refugee status; 2 years for nationals of Ibero-American countries, Andorra, the Philippines, Equatorial Guinea, Portugal, and those of Sephardic origin; 1 year for those who were born in Spanish territory, those who have been under protection for 2 years as an unaccompanied foreign minor, and those married to a Spaniard.

Right to asylum. The Spanish state recognizes the right to asylum in its Constitution and said right is recognized in the Asylum Law. This is a process that is made up of several phases: application, admission of the application for processing, investigation, and decision.

When the application is presented, the applicant is given a document to prove his/her status as an applicant for asylum. During the investigation process, six months after having requested asylum, said person is documented with a "red card," which proves their legal status in Spain and allows them to work temporarily in any place in the country as an employee of others and in any occupational area. Additionally, said card allows them to access regional financial assistance like the Canary Island Social Insertion Grant (E8).

In the last few years, different NGOs and, especially, the Spanish Commission for Refugees (CEAR), have denounced violations of the right to asylum in Spain: refusal of legal assistance, extremely long times for decisions, a high rate of denials (65\%), and "expedited returns" before the immigrant who has entered Spain illegally has time to request asylum. It must be taken into account that, in December of 2017, there were more than 39,000 pending applications to be decided on.

On the Canary Islands, throughout 2017, 820 applications for asylum were recorded, the majority of them were from people coming from Venezuela, the Western Sahara, and the Ukraine. Tenerife does not have a specialized service to advise those who apply for asylum, and the percentage of denials is even higher than in other parts of Spain. This is due to the fact that the 
majority of applications are by those of Venezuelan nationality, a collective whose percentage of denial reaches $99 \%$. In Spain, of the 1,530 applications for asylum filed by said collective, only 15 have been approved.

Immigrants' living conditions. According to a study conducted for the Permanent Observatory for Immigration in Spain on the different dimensions of integration for immigrants in different regions of Spain (Godenau et al., 2017), many of those who reside in the Canary Islands (whether they are immigrants or not) suffer from low salaries, high rates of unemployment, and precarious employment conditions. Of all the Spanish regions, the Canary Islands is where there are less differences recorded between foreigners and non-foreigners; however, this apparent integration success underscores the likewise unfavourable situation of non-foreigners (downward convergence). The occupational disadvantages of the immigrant population become particularly visible in terms of the issue of over-qualification, which indicates that some immigrants are not able to use their training on the local job market. The financial crisis has exacerbated these problems (Godenau y Buraschi, 2017a).

This occupational situation is the main limiting factor in terms of the difficulties that part of the population (immigrants) face to obtain the necessary income for the material wellbeing of their families. The corresponding indicators of inequality and poverty (Padrón Marrero, 2017, included in Godenau y Buraschi, 2017a) show that the immigrant population tends to have lower earnings and income than those born on the Canary Islands. In terms of social relationship and citizenship indicators, the situation is much more favourable because the passing of time has allowed for substantial improvements in terms of obtaining legal documentation and linguistic competence.

It must be remembered that immigrants are not representative of a homogeneous group: their life conditions on the Canary Islands vary a lot depending upon their country of origin, differences that are particularly related to their occupational situation, their household income, their family structure, and the years they have resided in Spain. Those of African origin are those who have most suffered from the effects of the financial crisis. According to a survey conducted by OBITen (Godenau y Buraschi, 2017a), 52.6\% of African immigrants have had to reduce their food expenses due to the financial crisis. This is compared with $11.0 \%$ for immigrants from the European Union. Regarding the family structure, immigrants who live in single-person households (made up of just one person) and single-parent households (one adult with dependent children) are those who have most difficulties to make ends meet. 


\section{Conclusions}

Tenerife has been, historically, a land of emigration (especially towards America) and of immigration (from Europe and, in the last three decades, from America and Africa). The Islands' historic and social bond with countries like Venezuela and Cuba have turned it into a vastly multinational space. Despite its close proximity to Morocco, immigration of African origin is not significantly high, with American and European immigration being much more important. Tenerife is both an area where immigrants simply pass through and a final destination for immigrants. It is the final destination of European immigration, especially Italian and German immigration, as they are attracted by the climate and the lower tax pressure. It is also the final destination for the vast amounts of immigrants coming from America and, more specifically, coming from Venezuela, as these immigrants have support networks on the Canary Islands, because there is a clear cultural affinity between the two locations and because "transnational family networks" have grown in strength in recent decades; that is to say, the vast majority of Latin American immigrants already have a family member living on the Island of Tenerife. On the other hand, Tenerife is a land of passage for illegal African immigration by sea, using the Canary Islands as a gateway to Europe. Currently, the irregular maritime migration flow is quite low.

The migratory past of the Canary Islands and the intense relationship that the Islands have with Latin America help to explain the positive attitudes that the population has towards immigration. Additionally, we must point out that there are numerous civil society initiatives, as well as initiatives promoted by local governments, whose aim is to promote intercultural coexistence and that have a positive impact on the population's attitudes. One of the main characteristics of these initiatives is that they use different participatory methodologies. In fact, participation and coordination between the NGOs, civil society, and local governments are probably the main strengths of the initiatives undertaken on the island.

Currently, 177thousand people of foreign origin reside on the Island of Tenerife: $19.8 \%$ of the population. It is a heterogeneous population (170 different countries), both from the point of view of the immigrants' countries of origin and from a point of view of living conditions. The territorial distribution of the immigrant population reflects the importance of the economic circumstances for this collective, with their presence being centred around the urban areas and in touristic areas. Illegal migration flows by sea were noteworthy during the year 2006 (34,000 arrivals); currently, this means of arrival is starting to be revived after having decreased significantly since 2008 . 
Spanish immigration policy has been characterized, especially during the years before the financial crisis, by a functionalist approach focused on labour and a certain degree of flexibility in terms of illegal immigration. In recent years, there has been less emphasis on the need of labour and funding for integration policies has been significantly reduced.

The "refugee crisis" of 2015 has not had a significant social impact on the island; however, it has revived different social initiatives whose aim is to raise awareness about, and defend the rights of, immigrants.

Lastly, throughout the fieldwork, different challenges have been identified, all of which are linked with the need to define an immigration policy based on human rights that is comprehensive, far-reaching, and participatory. This last aspect makes reference, especially, to the need to define a far-reaching national and European policy to cover from the outermost fringes of the border territories to the centre. That is to say, a European policy that takes into account the experiences, the needs, and the initiatives that are being undertaken in border territories. 


\section{Bibliography}

Alonso, B. S. (2011). La política migratoria en España Un análisis de largo plazo. Revista Internacional de Sociología, 69(M1), 243-268.

Anaya, S. M., Aguilar, F. J., \& Bautista, F. J. (2018). Actitudes hacia la inmigración en España a través de la Encuesta Social Europea. OBETS: Revista de Ciencias Sociales, 13(1), 93-119

Ardevol Abreu, A. (2008). La inmigración, en la fotografía de prensa de Canarias. Revista Latina de Comunicación Social, 11(63).

Asín Cabrera, M.A. y Godenau, D. (2014). Movilidad y Gran Vecindad en las regiones ultraperiféricas de la Unión Europea. Santa Cruz de Tenerife: Cabildo de Tenerife.

Buraschi, D. (2014). Estrategias identitarias delos emigrantes canarios retornados de Venezuela. Migraciones. Publicación del Instituto Universitario de Estudios sobre Migraciones, (35), 69-96.

Buraschi, D., Aguilar, M.J. y Zapata, V. (2016). Comunicación social antirracista participativa: la propuesta metodológica de los laboratorios dialógicos dela red antirrumores en Tenerife. Documentos de Trabajo: Seminario Permanente de Ciencias Sociales. Cuenca: Universidad de Castilla-La Mancha.

Buraschi, D., Aguilar, M.J., Oldano, N., Fonte, M.E. y Zapata, V. (2017). Comunicazione partecipativa e cultura dell'ospitalità. Educazione aperta, 11.

CEAR (2017), Refugiados y migrantes en España: Los muros invisibles tras la frontera sur, Madrid, Comisión Española de Ayuda al Refugiado.

El-Enany, N. (2016). Aylan Kurdi: the human refugee. Law and Critique, 27(1), $13-15$.

Fernández, M., Valbuena, C. y Caro, R. (2017). Evolución del racismo, la xenofobia y otras formas de intolerancia. Madrid: Ministerio de Empleo y Seguridad Social.

Godenau y Buraschi (eds.) (2017b), Migraciones, desigualdad e integración en tiempos de crisis. Santa Cruz de Tenerife: Cabildo de Tenerife.

Godenau, D. (2010). Una década de (in)migración: balance y perspectiva. Documentos OBITen. Tenerife: Observatorio de la Inmigración de Tenerife (OBITen).

Godenau, D. y Buraschi, D. (2017a), Movilidad y condiciones de vida de los inmigrantes durante la crisis económica en Tenerife. Santa Cruz de Tenerife: Cabildo de Tenerife.

Godenau, D., \& Zapata, V. (2008). Canarias: inmigración en una región fronteriza del sur de la Unión Europea. Política y sociedad, 45(1), 61-83. 
Godenau, D., Rinken, S., Martínez De Lizarrondo Artola, A., Moreno Márquez, G. (2017). La integración de los inmigrantes en España: fases, patrones y dinámicas regionales durante el período 2007-2015. Observatorio Permanente de la Inmigración. Madrid: Ministerio de Empleo y Asuntos Sociales de España.

González Rodríguez, R.; Mesa Marrero, A. y Zapata Hernández, V.M. (2016), "Retos para la gestión compartida de las políticas sociales en territorios municipales fronterizos: Taco en la conurbación capitalina de Tenerife", en Márquez, J. A.; Jurado J. M. y Pazos F. J. (coords.), Desarrollo local en territorios de fronteras, Huelva: Universidad de Huelva, pp. 419-429.

Izquierdo, A. (2008): "En la antesala de la recesión: inmigración y modelo migratorio", en Izquierdo, A. (coord.), El modelo de inmigración y los riesgos de exclusión. Madrid: Fundación FOESSA, , pp. 17-75.

López Sala, A. (2013): "Managing Uncertainty: Immigration Policies in Spain during Economic Recession (2008-2011)", Migraciones Internacionales, vol. 7, 2, 39-69.

Macías, A. (1992). La migración canaria, 1500-1980. Gijón: Júcar.

Mesa, A., Ramallo, J., Zapata, V. (2012). Juntos En la misma dirección: Nuevos métodos para viejos retos en contexto de creciente diversidad humana. Documentos OBITen. Tenerife: Observatorio de la Inmigración de Tenerife (OBITen).

Rinken, S. (2015). Actitudes hacia la inmigración y los inmigrantes: ¿en qué es España excepcional? Migraciones. Publicación del Instituto Universitario de Estudios sobre Migraciones, (37), 53-74.

Rodríguez Borges, R. F. (2010). Discurso xenófobo y fijación de agenda. Un estudio de caso en la prensa de Canarias (España). Revista Latina de Comunicación Social, (65).

Zapata Hernández, V. M., \& Ramallo Rodríguez, J. (2015). Los observatorios de la inmigración como estructuras de intervención social. En F. J. García Castaño, A. Megías Megías, \& J. Ortega Torres (Eds.), Actas del VIII Congreso sobre Migraciones Internacionales en España (Granada, 16-18 de septiembre de 2015) (pp. S22/27- S22/38). Granada: Instituto de Migraciones.

Zapata Hernández, V.M. (2013), "Gestión intercultural con enfoque socioterritorial: el protagonismo del mundo asociativo", en Zapata-Barrero, R. y Pinyol, G. (eds.), Manual para el diseño de políticas interculturales, Barcelona: GRITIM-Universitat Pompeu Fabra, pp. 121-134.

Zapata Hernández, V.M. (2016), "Del estudio de la población al trabajo con la comunidad para el fortalecimiento de la convivencia en la diversidad", en Sempere, J.D. y Cutillas, E. (coords.), La población en España. 40 años de cambio (1975-2015), Alicante: Publicacions de la Universitat D’Alacant, pp. 291-306. 


\begin{tabular}{|c|c|c|c|c|}
\hline \multirow[t]{13}{*}{$\begin{array}{r}\text { ANNEX } \\
\text { List of interviews }\end{array}$} & Code & Date & $\begin{array}{l}\text { Name (preserve } \\
\text { participants identity) }\end{array}$ & Short bio \\
\hline & E1 & $22 / 07 / 18$ & Dirk Godenau & $\begin{array}{l}\text { Professor of applied economics from the } \\
\text { University of La Laguna and Scientific } \\
\text { director of the Immigration Observatory } \\
\text { of Tenerife. }\end{array}$ \\
\hline & E2 & $21 / 09 / 18$ & Vicente Zapata & $\begin{array}{l}\text { Professor of human geography and } \\
\text { Academic Director of the Immigration } \\
\text { Observatory of Tenerife. }\end{array}$ \\
\hline & E3 & $26 / 07 / 18$ & Julio Ramallo & $\begin{array}{l}\text { Head of the Data Bank Unit and } \\
\text { Documentation Centre of the } \\
\text { Socioeconomic and Commerce } \\
\text { Development Technical Service. } \\
\text { Department of Employment, } \\
\text { Commerce, Industry, and } \\
\text { Socioeconomic Development. Tenerife } \\
\text { Island Council. Technical Director } \\
\text { of the Immigration Observatory of } \\
\text { Tenerife. }\end{array}$ \\
\hline & E4 & $01 / 10 / 18$ & Amal Belleyo & $\begin{array}{l}\text { A } 21 \text {-year-old young man. The daughter } \\
\text { of Moroccan immigrants, a practicing } \\
\text { Muslim and social worker. }\end{array}$ \\
\hline & E5 & $30 / 07 / 18$ & Alexis Mesa & $\begin{array}{l}\text { Person in charge of the Intercultural } \\
\text { Community Intervention Project, Taco. }\end{array}$ \\
\hline & E6 & $22 / 07 / 18$ & María Fonte & $\begin{array}{l}\text { Person in charge of the Together in the } \\
\text { Same Direction Project. }\end{array}$ \\
\hline & E7 & $01 / 10 / 18$ & Arancha Méndez & $\begin{array}{l}\text { Person in charge of the Immigrant } \\
\text { Program at Cáritas Diocese of Tenerife. }\end{array}$ \\
\hline & E8 & $01 / 10 / 18$ & Ester Cataldo & Lawyer specialized in immigration law. \\
\hline & E9 & $18 / 09 / 18$ & Carlos Benítez & $\begin{array}{l}\text { Social anthropologist who works with } \\
\text { the Immigration Observatory of Tener- } \\
\text { ife. }\end{array}$ \\
\hline & E10 & $30 / 07 / 18$ & Oliver G. & $\begin{array}{l}25 \text {-year-old immigrants of Nigerian } \\
\text { origin who arrived illegally in } 2015 \text { by } \\
\text { sea. }\end{array}$ \\
\hline & E11 & $25 / 08 / 18$ & Valentina Mitilleri & $\begin{array}{l}\text { Italian immigrant, social anthropologist, } \\
\text { member of the Factoria Social } \\
\text { Association. }\end{array}$ \\
\hline & E12 & $31 / 07 / 18$ & Teresa Budroni & $\begin{array}{l}\text { Italian immigrant who is a member of } \\
\text { the "CONRed" intercultural community } \\
\text { project. }\end{array}$ \\
\hline
\end{tabular}




\begin{tabular}{|c|c|c|c|}
\hline Code & Date & $\begin{array}{l}\text { Name (preserve } \\
\text { participants identity) }\end{array}$ & Short bio \\
\hline E13 & $30 / 07 / 18$ & Roberto Carpio & $\begin{array}{l}\text { Young, 12-year-old immigrant of } \\
\text { Venezuelan origin, son of a mixed } \\
\text { "interracial" couple. }\end{array}$ \\
\hline E14 & $30 / 07 / 18$ & Cindy Hidalgo & $\begin{array}{l}\text { A } 42 \text {-year-old immigrant of Venezuelan } \\
\text { nationality. After having resided in } \\
\text { Spain illegally for } 3 \text { years, he was able } \\
\text { to regularize his legal situation of } \\
\text { residence in Tenerife. }\end{array}$ \\
\hline E15 & $22 / 07 / 18$ & Nasara Cabrera & $\begin{array}{l}\text { Sociology professor at the University of } \\
\text { Las Palmas de Gran Canaria. Expert in } \\
\text { immigration and gender. }\end{array}$ \\
\hline E16 & $12 / 09 / 18$ & $\begin{array}{l}\text { Sara González Per- } \\
\text { domo. Irene Loren- } \\
\text { zo Pérez y Marina } \\
\text { Martín Baute }\end{array}$ & $\begin{array}{l}\text { Children and youth who participate in } \\
\text { the "Amiguitos y Amiguitas" ("Friends") } \\
\text { participatory group of the "Together in } \\
\text { the Same Direction" Strategy. }\end{array}$ \\
\hline E17 & $13 / 09 / 18$ & $\begin{array}{l}\text { Roxana Dinah María } \\
\text { Resnikowski }\end{array}$ & $\begin{array}{l}\text { Immigrant woman of Bolivian origin. } \\
\text { Social activist and member of different } \\
\text { collectives that defend the rights of } \\
\text { immigrants. }\end{array}$ \\
\hline E18 & 19/07/18 & Anselmo Fariña. & $\begin{array}{l}\text { Social activist and founding member of } \\
\text { "Candelaria por la paz y el derecho al } \\
\text { refugio" ("Candelaria for peace and the } \\
\text { right to refuge"). }\end{array}$ \\
\hline E19 & 05/10/18 & Karima El Mahmdi & $\begin{array}{l}\text { Social worker of Moroccan origin, head } \\
\text { of the Spanish Red Cross's immigration } \\
\text { program. }\end{array}$ \\
\hline E20 & 05/10/18 & Abdouraham C. & $\begin{array}{l}\text { Immigrant of Guinean origin (Guinea } \\
\text { Conakry) who is } 30 \text { years old and lived } \\
\text { in France, Switzerland, and Portugal } \\
\text { before coming to Span } 5 \text { years ago. He } \\
\text { was able to regularize his immigration } \\
\text { status after having lived in Spain for } 4 \\
\text { years without a residence permit. }\end{array}$ \\
\hline E21 & 16/09/18 & Audrey Monnier. & $\begin{array}{l}\text { Young French entrepreneur residing in } \\
\text { Tenerife since } 2010 \text {. }\end{array}$ \\
\hline E22 & 04/09/18 & Reyes Henríquez & $\begin{array}{l}\text { Director General of Social Policy and } \\
\text { Immigration for the Government of the } \\
\text { Canary Islands. }\end{array}$ \\
\hline E23 & $04 / 09 / 18$ & Rosario Rodríguez & $\begin{array}{l}\text { Technician from the Directorate General } \\
\text { of Social Policy and Immigration for the } \\
\text { Government of the Canary Islands. }\end{array}$ \\
\hline
\end{tabular}




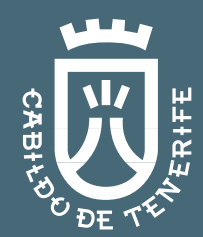

4 Universidad

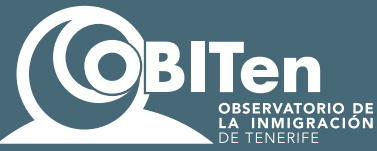

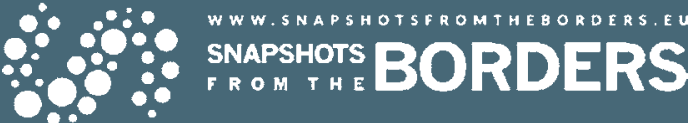

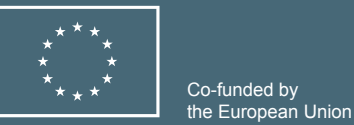

